\title{
Prediction of the suitability of soya-bean products for feeding to preruminant calves by an in-vitro immunochemical method
}

\author{
BY J. W. SISSONS, R. H. SMITH AND D. HEWITT \\ National Institute for Research in Dairying, Shinfield, Reading RG2 9AT \\ AND A. NYRUP \\ Aarhus Oliefabrik A/S, PO Box 50,DK-8100 Aarhus C., Denmark
}

(Received 16 July 1981 - Accepted 29 October 1981)

\begin{abstract}
1. An immunochemical test for predicting the suitability of different soya-bean products for feeding to preruminant calves was studied. Calves fitted with abomasal and re-entrant ileal cannulas, were first given a series of feeds containing heated soya-bean flour and two with casein as the protein source, and then given further test feeds in which different experimental soya-bean products, prepared under conditions which might be used commercially, provided the nitrogren source. These products $(Q, R, S$ and $T)$ were prepared respectively by extracting fat-free soya-bean flour with aqueous ethanol at $960,650,650$ and $550 \mathrm{ml} / 1$ and at $60,60,78$ and $78^{\circ}$ and then treating the residue with steam for $30 \mathrm{~min}$.

2. After infusion of a test feed into the abmasum measurements were made of transit time through the small intestine, flow-rate of ileal digesta, recovery of polyethylene glycol (a water-soluble marker added to the feed) and net $\mathrm{N}$ absorption up to the distal ileum. Glycinin and $\beta$-conglycinin, antigenic constituents of soya-bean protein, were determined in saline ( $9 \mathrm{~g}$ sodium chloride/I) extracts of soya-bean products by haemagglutination inhibition assay.

3. After calves had been given a series of four feeds containing heated soya-bean flour, they showed hypersensitivity to the flour by developing disturbances in digesta movement and $\mathrm{N}$ uptake. When experiments were made to compare the effects of giving feeds based on casein with those containing products $\mathrm{R}, \mathrm{S}$ and $\mathrm{T}$ it was shown that some differences in transit times and flow-rates of digesta through, and $\mathrm{N}$ absorption from, the small intestine occurred. Disturbances were, however, much less than those observed with product $Q$ feeds.

4. Haemaggultination inhibition assay of products $Q, R, S$ and $T$ gave titres $\left(\log _{2}\right.$ reciprocal of highest dilution of saline extract inhibiting agglutination) of 12,5,3 and 2 for glycinin and 13,3, 3 and 2 for $\beta$-conglycinin respectively. After steam treatment only product $Q$ gave measurable titres; 10 and 11 for glycinin and $\beta$-conglycinin respectively.

5 . It is concluded that the haemagglutination inhibition assay is a suitable in vitro method of indicating whether soya-bean products given in liquid feeds to preruminant calves will cause gastrointestinal allergic reactions. Furthermore, results show that the removal of deleterious factors from soya-bean meal by treating with ethanol, is critically dependent on the proportion of water present in the ethanol and the temperature of the treatment.
\end{abstract}

In earlier experiments cannulated calves given a succession of liquid feeds containing heated soya-bean flour developed abnormalities in digestive processes; such feeds led to inhibition of abomasal emptying, rapid passage and high flow rates of digesta through the small intestine and decreased absorption of dietary nitrogen (Smith \& Sissons, 1975; Sissons \& Smith, 1976). The pattern of development of the disorders and the fact that the deleterious feeds gave rise to the production of circulatory antibodies (Smith \& Sissons, 1975) suggested that allergenic constituents in the soya-bean flour were responsible. Subsequent work showed that responses of serum antibodies to constituents of soya-bean flour were related to the severity of these digestive disorders (Smith \& Sissons, 1975; Kilshaw \& Sissons, 1979a) and, in other studies, coincided with morphological changes in the villi and lamina propria (Barratt $e$ t al. 1978) similar to those of villous atrophy observed in a human infant showing intolerance to soya-bean protein (Ament \& Rubin, 1972). A dramatic increase in the permeability of the gut wall to macromolecules normally excluded by the mucosal barrier has also been shown to occur (Kilshaw \& Slade, 1980). 
Immunochemical studies indicated that in calves given soya-bean products, serum antibody responses were evoked by storage globulins of soya-bean, glycinin and $\beta$-conglycinin (Kilshaw \& Sissons, 1979a). This view is supported by observations that soya-bean concentrate prepared by hot aqueous-ethanol extraction of soya-bean meal neither caused digestive disturbances in calves nor contained immunologically active glycinin or $\beta$ conglycinin, whilst heated soya-bean flour and soya-bean protein isolate both contained large amounts of these globulins and provoked gastrointestinal disorders (Sissons \& Smith, 1976; Kilshaw \& Sissons, 1979a). The present study was designed to examine if an in vitro immunochemical assay for detecting glycinin and $\beta$-conglycinin would predict the extent to which different soya-bean products may cause gastrointestinal disorders in calves. Particular attention was given to conditions of ethanol extraction similar to those that might be encountered in commercial processing of soya-bean products.

\section{METHODS}

\section{Animals}

Calves. Four friesian bull calves were equipped with a simple cannula in the fundic region of the abomasum and a re-entrant cannula in the distal ileum as described by Sissons \& Smith (1976). Cannulas were inserted when calves were 3 weeks of age.

Calves received colostrum up to $4 \mathrm{~d}$ of age and then whole milk supplemented from 3 weeks with minerals and vitamins (Smith \& Sissons, 1975). Supplements of aureomycin (Cyanamid Agricultural Division, Gosport, Hants) were added to each feed $(0 \cdot 4 \mathrm{~g} / \mathrm{d})$ from $\mathrm{l}$ week after the cannulation operation. Calves were kept on this regimen except on days when they were given single experimental feeds.

\section{Experimental diets}

Experimental feeds were given to calves, by direct infusion into the abomasum, from approximately 3 weeks after surgery when animals were 6 weeks of age. The composition of these feeds has been described previously (Smith \& Sissons, 1975) and included either calcium caseinate or a soya-bean product as the only protein source. Sometimes experimental feeds were prepared from heated soya-bean flour (product B) also described previously by Smith \& Sissons (1975). A series of such feeds were given, followed by feeds of other products which were prepared by extracting three times 1 part fat-free but untoasted soya-bean flakes with 4 parts aqueous-ethanol of different concentrations at different temperatures for $1 \mathrm{~h}$. The concentrations $(\mathrm{ml}$ ethanol/1 water) and temperatures were 960 at $60^{\circ}, 650$ at $60^{\circ}, 650$ at $78^{\circ}$ and 550 at $78^{\circ}$ for products $Q, R, S$ and T respectively. The products were then dried using hot air at $75^{\circ}$ and steamed for $30 \mathrm{~min}$. The conditions used in preparing products $\mathrm{R}, \mathrm{S}$ and $\mathrm{T}$ were similar to those believed to be used in the commercial processing of ethanol extracted soya-bean concentrates. Amounts ( $\mathrm{g} / \mathrm{kg}$ liquid diet) of the soya-bean products added were $66,57,47,48$ and 48 for products $\mathrm{B}, \mathrm{Q}, \mathrm{R}, \mathrm{S}$ and $\mathrm{T}$ respectively. All feeds contained 5 g polythene glycol (molecular weight 4000 ; PEG) and $0 \cdot 1 \mathrm{~g}$ phenol red as markers.

\section{Digesta collection}

Collections of digesta from the distal ileum of calves were made after giving one of the experimental feeds and measurements were made of small intestine transit time, mean rates of ileal digesta flow, recoveries of PEG and net disappearance of $\mathrm{N}$ between mouth and ileum as described by Sissons \& Smith (1976, 1978).

At the beginning of the experiments each of the four calves was given an experimental feed prepared from casein and then a series of four experimental feeds containing heated soya-bean flour (product B). At this stage the animals were regarded as being sensitized 
to antigenic constituents of the flour (see Sissons \& Smith, 1976; Kilshaw \& Sissons, $1979 b$ ). The sensitized calves were then each given feeds containing products $Q, R, S$ and $T$ in random order according to a Latin Square design. In principle, challenging a calf previously sensitized to heated soya-bean flour with another soya-bean product containing antigenic constituents was expected to provoke further gastrointestinal disorders. The severity of these disorders was then compared with the amounts of immunogenically-active glycinin and $\beta$-conglycinin in the product.

During some experiments mainly with product $\mathbf{S}$ feeds, leakages of ileal contents occurred at the cannula because the apparatus failed to pump digesta into the collection vessel. To obtain sufficient measurements further experimental collections were made with casein and heated soya-bean flour feeds and then experiments with products $Q, R, S$ and $T$ were repeated in a second Latin Square experiment, but using a different randomization.

Test feeds were given at intervals of $2-3 \mathrm{~d}$ so that a Latin Square experiment was done over a period of 7-10 d. There was a period of $5 \mathrm{~d}$ between the first and second Latin Square experiments.

\section{Analytical methods}

Total $N$. Samples of homogenized digesta $(1 \mathrm{~g})$, liquid diet $(1 \mathrm{~g})$, saline $(9 \mathrm{~g}$ sodium chloride/l) extract of a soya-bean protein $(2 \mathrm{ml})$ or dietary protein source $(0.1 \mathrm{~g})$ were digested as described by Smith \& Sissons (1975) and the ammonia-N produced was estimated colorimetrically using an automated technique (Technicon Instruments Co. Ltd, 1967).

$P E G$. The amount of PEG in digesta samples was determined by the method described by Smith $(1958,1962)$ except that $20 \mathrm{~min}$ was allowed for the development of turbidity. Phenol red, when it was present, was first removed from the samples according to Smith (1964).

Haemagglutination inhibition. Soya-bean products $(3 \mathrm{~g})$ were extracted with $0 \cdot 15 \mathrm{M}-\mathrm{NaCl}$ $(15 \mathrm{ml})$ for $1 \mathrm{~h}$ at $25^{\circ}$ whilst maintaining the $\mathrm{pH}$ at 6.7 by adding $1 \mathrm{M}$-sodium hydroxide as required. Saline extractions were made at a $\mathrm{pH}$ of 6.7 because the experimental feeds were adjusted to this $\mathrm{pH}$ before abomasal infusion, and nearly maximum solubility of protein occurs at this value (Wolf, 1970). Amounts of glycinin and $\beta$-conglycinin present in saline extracts of soya-bean products were determined by haemagglutination inhibition as described previously (Kilshaw \& Sissons, 1979 b).

Statistical analysis. Treatment differences obtained in the second Latin Square experiment were examined by analysis of variance. Mean values, including one missing value for product $S$ feeds, are given in Table 2 together with least significant differences for $P=0.05$. Such treatment of the results obtained in the first Latin Square is not reported because, owing to the number of observations that were lost, there were few error degrees of freedom.

\section{RESULTS}

Digesta flow and $N$ utilization after calves received feeds containing casein or different soya-bean products

In earlier studies (Smith \& Sissons, 1975; Sissons \& Smith, 1976; Kilshaw \& Sissons, 1979a) with cannulated calves severe gastrointestinal hypersensitive reactions to antigenic constituents of soya-bean occurred only after animals were given several feeds of heated soya-bean flour. In the present studies calves given a succession of heated-soya-bean-flour feeds showed disturbances in digesta movement through the small intestine and absorption of dietary $\mathbf{N}$ quantitatively similar to those reported previously (Sissons \& Smith, 1976).

In general these disturbances developed progressively, but the extent of the disorders varied in the different calves. Values of small intestine transit time, mean rates of digesta flow, recoveries of PEG and net disappearance of $N$ between mouth and ileum for calves 


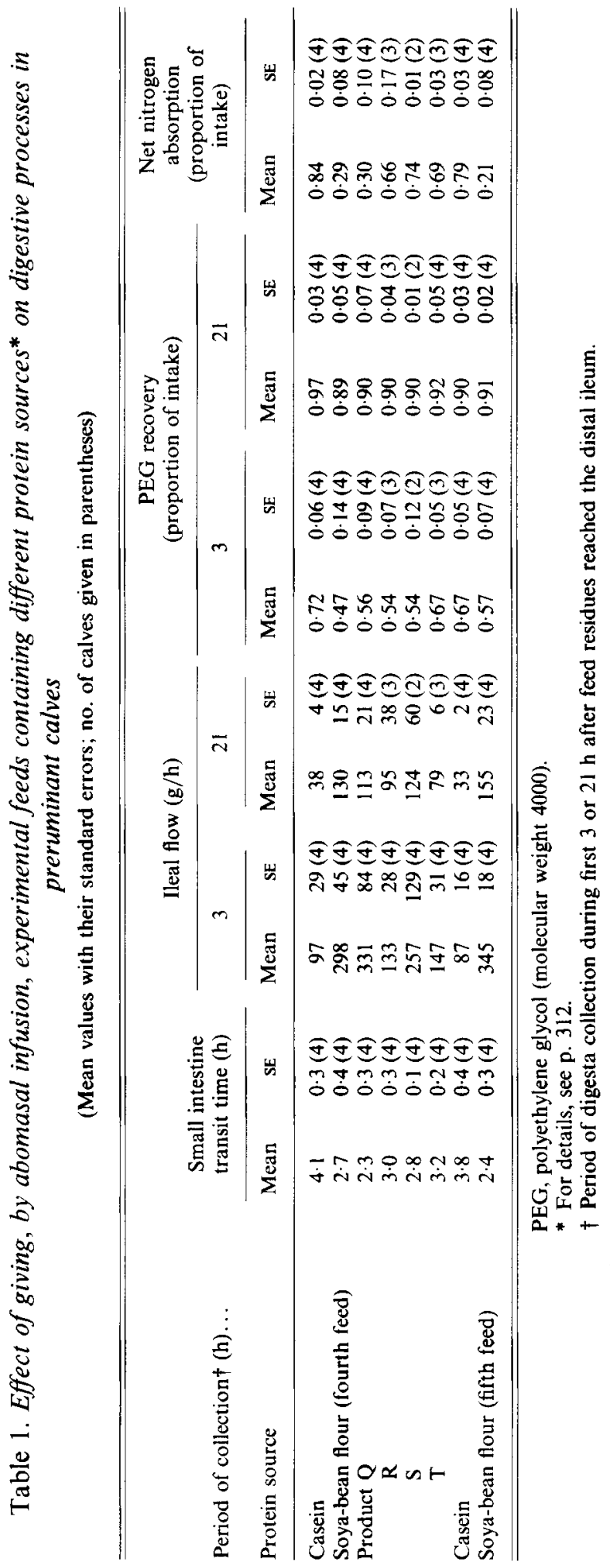


Table 2. Effect of giving by abomasal infusion, experimental feeds containing different soya-bean products* on digestive processes in sensitized calves $\dagger$

(Values are based on individual results for four calves, except for product $\mathrm{S}$ which includes one missing value)

\begin{tabular}{|c|c|c|c|c|c|c|}
\hline \multirow{2}{*}{$\begin{array}{l}\text { Period of } \\
\text { collection } \ddagger(h) . .\end{array}$} & \multirow{2}{*}{$\begin{array}{c}\text { Small } \\
\text { intestine } \\
\text { transit } \\
\text { time }(\mathrm{h})\end{array}$} & \multicolumn{2}{|c|}{$\begin{array}{c}\text { Ileal } \\
\text { flow }(\mathrm{g} / \mathrm{h})\end{array}$} & \multicolumn{2}{|c|}{$\begin{array}{l}\text { PEG recovery } \\
\text { (proportion of } \\
\text { intake) }\end{array}$} & \multirow{2}{*}{$\begin{array}{l}\text { Net nitrogen } \\
\text { absorption } \\
\text { (proportion of } \\
\text { intake) }\end{array}$} \\
\hline & & 3 & 21 & 3 & 21 & \\
\hline \multicolumn{7}{|l|}{ Soya-bean product } \\
\hline $\mathrm{Q}$ & 1.9 & 602 & 235 & 0.48 & 0.86 & 0.06 \\
\hline $\mathbf{R}$ & $2 \cdot 5$ & 175 & 74 & 0.63 & 0.93 & 0.69 \\
\hline $\mathbf{S}$ & 2.6 & 241 & 82 & 0.46 & 0.70 & 0.58 \\
\hline $\mathrm{T}$ & $2 \cdot 8$ & 116 & 56 & 0.52 & 0.86 & $0 \cdot 76$ \\
\hline LSD & 0.6 & 125 & 42 & $0 \cdot 16$ & $0 \cdot 12$ & 0.14 \\
\hline
\end{tabular}

PEG, polyethylene glycol (molecular weight 4000); LSD, least significant difference $(P=0.05)$ based on the error mean square with $5 \mathrm{df}$ in the analysis of variance.

* For details, see p. 312.

$\uparrow$ Experimental feeds containing soya-bean product B had been given on five previous occasions, see p. 312 .

$\ddagger$ Period of digesta collections during first 3 or $21 \mathrm{~h}$ after food residues reached the distal ileum.

receiving casein feeds or heated soya-bean flour feeds given on a fourth and fifth occasion are shown in Table 1. Compared to values for casein, measurements for heated soya-bean flour on the fourth or fifth feed were markedly different; values of transit time and net $\mathrm{N}$ absorption were considerably lower and mean rates of ileal digesta flow were higher.

Following sensitization to heated soya-bean flour, calves were given experimental feeds containing products $Q, R, S$ and $T$ to examine possible relationships between severity of gastrointestinal hypersensitive responses and amount of glycinin and $\beta$-conglycinin by an in vitro immunochemical asssay of the different products. Measurements of the effects of these soya-bean products on digestive processes obtained in the first and second Latin Square experiments are given in Tables 1 and 2 respectively. After receiving experimental feeds containing products $\mathrm{R}, \mathrm{S}$ or $\mathrm{T}$ calves showed significantly higher values of small intestine transit time and $\mathrm{N}$ absorption $(P<0.05$ and $P<0.001$ respectively, see Table 2$)$ significantly lower values $(P<0.001$, see Table 2$)$ for 3 and $21 \mathrm{~h}$ ileal digesta flow than corresponding measurements obtained for product $Q$ feeds. Results when products $R, S$ and $T$ were given to calves were closely similar to previously reported values for sensitized animals given feeds containing soya-bean meal treated or extracted with ethanol (Sissons et al. 1979). In the analysis of variance the differences between products $R, S$ and $T$, with the exception of 21 h PEG recovery, were not significant. However, values of PEG recovery and net $\mathrm{N}$ absorption obtained for product $\mathrm{S}$ in the second Latin Square experiment were considerably lower than for products $\mathrm{R}$ and $\mathrm{T}$. These results suggest that after giving product $\mathbf{S}$ the passage of dietary $\mathbf{N}$ between the abomasum and distal ileum was slower than that after giving feeds containing products $R$ and $T$. In contrast to values obtained after giving feeds containing products $\mathrm{R}, \mathrm{S}$ and $\mathrm{T}$, results obtained for product $\mathrm{Q}$ feeds were not markedly different from those observed when sensitized animals were given feeds of heated soya-bean flour on four or more previous occasions (see Table 1).

\section{Antigenic constituents in soya-bean products}

Earlier immunochemical studies (Kilshaw \& Sissons, 1979b) of different soya-bean products showed variations in soluble glycinin and $\beta$-conglycinin according to conditions 
Table 3. Quantities of crude protein, glycinin and $\beta$-conglycinin in extracts* of different soya-bean products $\dagger$

\begin{tabular}{|c|c|c|c|c|}
\hline \multirow[b]{2}{*}{$\begin{array}{l}\text { Soya-bean } \\
\text { product }\end{array}$} & \multicolumn{2}{|c|}{$\begin{array}{l}\text { Crude protein } \\
\text { (nitrogen } \times 6 \cdot 25 \text { ) } \\
\text { content of: }\end{array}$} & \multicolumn{2}{|c|}{$\begin{array}{c}\log _{2} \text { reciprocal of highest } \\
\text { dilution of extract inhibiting } \\
\text { agglutination by: }\end{array}$} \\
\hline & $\begin{array}{l}\text { Whole } \\
\text { product } \\
\text { (mg/g) }\end{array}$ & $\begin{array}{c}\text { Saline } \\
\text { extract } \\
(\mathrm{mg} / \mathrm{ml})\end{array}$ & $\begin{array}{l}\text { Anti- } \\
\text { glycinin }\end{array}$ & $\begin{array}{c}\text { Anti- } \\
\beta \text {-conglycinin }\end{array}$ \\
\hline $\mathbf{Q}$ & 617 & 63.1 & 12 & 13 \\
\hline$R$ & 745 & 6.9 & 5 & 3 \\
\hline$S$ & 739 & $5 \cdot 0$ & 3 & 3 \\
\hline$T$ & 730 & $3 \cdot 8$ & 2 & 2 \\
\hline $\begin{array}{c}\beta \text {-conglycinin } \\
(4.7 \mathrm{mg} / \mathrm{ml})\end{array}$ & - & - & neg $\ddagger$ & 11 \\
\hline $\begin{array}{l}\text { Glycinin } \\
(0.46 \mathrm{mg} / \mathrm{ml})\end{array}$ & - & - & 7 & neg + \\
\hline
\end{tabular}

* For details of extraction, see p. 313. Extractions were made on soya-bean products before steaming.

$\dagger$ For details of preparation, see p. 313.

+ Negative value indicates no inhibition of agglutination.

of processing. Glycinin and $\beta$-conglycinin were not detected in commercial soya-bean concentrates prepared by extracting soya-bean meal with hot aqueous-ethanol at reported temperatures of $65-80^{\circ}$. These antigenic constituents appeared however to be fairly resistant to denaturation by treatments such as hexane extraction of oil from crushed soya beans and steam treatment used in the preparation of soya-bean flour as well as the acid and alkali treatments used for processing soya-bean isolates. Measurements of glycinin and $\beta$ conglycinin in saline extracts of soya-bean products $Q, R, S$ and $T$ prepared by extracting soya-bean flakes with varying concentrations of aqueous-ethanol at different temperatures are shown in Table 3. Values obtained for product $Q$ indicated that treatment conditions of $960 \mathrm{ml}$ ethanol $/ \mathrm{l}$ at $60^{\circ}$ were not effective for the destruction of antigenic activity of glycinin and $\beta$-conglycinin. Results for products $\mathrm{R}, \mathrm{S}$ and $\mathrm{T}$ showed that considerable denaturation of these antigens was achieved at ethanol concentrations of between 550 and $650 \mathrm{ml} / \mathrm{l}$ and there was some indication that with a treatment temperature of $78^{\circ}$ rather than $60^{\circ}$ there was less antigenic activity of glycinin. Further denaturation of glycinin and $\beta$-conglycinin occurred after treating soya-bean products $Q, R, S$ and $T$ with steam for $30 \mathrm{~min}$. After such treatment antigens were not detected in saline extracts of steamed products $\mathrm{R}, \mathrm{S}$ and $\mathrm{T}$, and reduced titres $\left(\log _{2}\right.$ reciprocal of the highest dilution of extract inhibiting agglutination) of 10 and 11 for glycinin and $\beta$-conglycinin respectively were obtained for product $\mathrm{Q}$ treated similarly.

\section{DISCUSSION}

Indirect evidence from previous studies suggests that major globulins in soya-bean protein, i.e. glycinin and $\beta$-conglycinin, are capable of provoking gastrointestinal hypersensitive reactions in preruminant calves (Smith \& Sissons, 1975; Sissons \& Smith, 1976; Kilshaw $\&$ Sissons, $1979 a$ ). This intolerance to soya-bean protein by calves was demonstrated with several commercial soya-bean products prepared in various ways, all of which contained substantial quantities of the antigenic constituents (Kilshaw \& Sissons, 1979b). These observations imply that an in vitro immunochemical assay for estimating immunogenic activity might be used to predict the effectiveness of treatment conditions to remove antigens from soya beans. 
In the present work haemagglutination inhibition assay of immunogenically active glycinin and $\beta$-conglycinin in saline extracts of experimental products gave low titres for products $\mathrm{R}, \mathrm{S}$ and $\mathrm{T}$ (see Table 3 ). From these results it is predicted that treatment of soyabean meal with $650 \mathrm{ml}$ ethanol $/ 1$ at 60 or $78^{\circ}$, or $550 \mathrm{ml}$ ethanol $/ 1$ at $78^{\circ}$ would improve the feeding value of the product for the calf. This view is supported by results given in Tables 2 and 3 showing that products $R, S$ and $T$ did not cause severe disturbances in digestive processes in cannulated calves. The in vitro results are also consistent with growth and digestibility trials in which calves given milk substitutes containing commercial soya-bean concentrates prepared by ethanol extraction showed markedly better performances than animals receiving heated soya-bean flour (Gorrill \& Thomas, 1967; Gorrill \& Nicholson, 1969, 1972; Nitsan et al. 1972). In contrast, high haemagglutination inhibition titres obtained for product $Q$ (see Table 3) are similar to those reported previously for heated soya-bean flour (Kilshaw \& Sissons, $1979 \mathrm{~b}$ ) and predict that extracting soya-bean meal with concentrated ethanol at $60^{\circ}$ would probably have little or no benefit for calf feeding. In fact, these in vitro results showing relatively high levels of antigens in product $Q$ are in agreement with observations of digestive disorders in calves given feeds containing the product (see Tables 2 and 3).

In selecting the extraction conditions for preparing the products used in the present study treatments were chosen that would be of commercial interest. It would have been preferable if the comparison between the in vitro and in vivo methods of evaluating these products had included products having intermediate immunological activities. However, as the in vitro immunochemical assay and the animal tests were conducted concurrently the likely outcomes of the experiments were not certain at the beginning of the study. Nevertheless, since the results of the immunochemical assay predicted not only that product $Q$ would cause digestive disorders when fed to calves, but also that treatments for preparing products $\mathrm{R}, \mathrm{S}$ and $\mathrm{T}$ would be beneficial, the in vitro method may be suitable for use by commercial organisations for monitoring the value of soya-bean products as a protein source in calf milk replacers.

Present results showing variations between the different experimental products in antigenic activity and effects on digestive processes are consistent with observations that soya-bean globulins are fairly resistant to denaturation by ethanol of high concentration, but sensitive to treatment with lower concentrations of ethanol (Roberts \& Briggs, 1963; Fukushima, 1969). The molecular structure of soya-bean globulins appears to be stabilized by both hydrophillic and hydrophobic bonds (Fukushima, 1969). Thus, to disrupt the protein it appears to be necessary to process soya-bean products with a solvent containing appropriate proportions of water and ethanol. The fact that soya-bean globulins remain immunogenically active in soya-bean concentrates prepared under certain conditions may possibly explain a finding reported by Barratt $e t$ al. (1978) that calves fed an unspecified soya-bean meal treated with ethanol showed high titres of serum antibodies to the product.

In agreement with results reported by Shibasaki et al. (1980) limited results in the present work indicate that steam treatment of the experimental products reduced the level of immunogenic activity slightly and may have contributed to the improvement in the utilization of products $R, S$ and $T$ by cannulated calves. These observations are consistent with an earlier finding (Smith \& Sissons, 1975) that calves given experimental feeds containing lightly steamed soya-bean flour showed digestive abonormalities that were more severe than when the animals received fully heated flour. Nitsan et al. (1971) reported that the feeding value of a calf milk substitute containing soya-bean meal extracted with ethanol was improved by treating the soya-bean concentrate with steam. Some of the benefit of steam treatment may, however, have been due to the destruction of heat labile trypsin inhibitor (Rackis, 1966).

It is well known that the solubility of globular soya-bean protein varies under different 
conditions of acidity (Wolf, 1970). In the in vitro immunochemical assay extracting soya-bean products in saline at a $\mathrm{pH}$ higher than 6.7 may possibly solubilize additional quantities of immunogenically active glycinin and $\beta$-conglycinin. However, since the values obtained by the in vitro assay were compared with measurements of changes in digestive processes it seems reasonable to extract the products at the $\mathrm{pH}$ of abomasal digesta immediately after feeding (Smith \& Sissons, 1975).

In conclusion, the present results show the importance of controlling conditions of solvent concentration and temperature of treatment during the processing of soya-bean concentrates for calf feeding. Measurements of undenatured glycinin and $\beta$-conglycinin in soya-bean protein by haemagglutination inhibition assay may be used to predict the extent to which different products are likely to provoke gastrointestinal allergic reactions in preruminant calves.

The authors thank Dr H. L. Buttle for carrying out all surgical operations and Mrs C. P. Chard for care of the experimental animals. Thanks are also expressed to Dr P. J. Kilshaw for providing samples of purified soya-bean proteins and to Aarhus Oliefabrik, Denmark for preparing experimental soya-bean products.

\section{REFERENCES}

Ament, M. E. \& Rubin, C. E. (1972). Gastroenterology 62, 227.

Barratt, M. E. J., Strachan, P. J. \& Porter, P. (1978). Clin. exp. Immunol. 31, 305.

Fukushima, D. (1969). Cereal Chem. 46, 156.

Gorrill, A. D. L. \& Nicholson, J. W. G. (1969). Can. J. Anim. Sci. 49, 315.

Gorrill, A. D. L. \& Nicholson, J. W. G. (1972). Can. J. Anim. Sci. 52, 465.

Gorrill, A. D. L. \& Thomas, J. W. (1967). J. Nutr. 92, 215.

Kilshaw, P. J. \& Sissons, J. W. (1979 a). Res. vet. Sci. 27, 361.

Kilshaw, P. J. \& Sissons, J. W. (1979 b). Res. vet. Sci. 27, 366.

Kilshaw, P. J. \& Slade, H. (1980). Clin. exp. Immunol, 41, 575.

Nitsan, Z., Volcani, R., Gordin, S. \& Hasdai, A. (1971). J. Dairy Sci. 54, 1294.

Nitsan, Z., Volcani, R., Hasdai, A. \& Gordin, S. (1972). J. Dairy Sci. 55, 811.

Rackis, J. J. (1966). J. Fd Technol. 20, 102.

Roberts, R. C. \& Briggs, D. R. (1963). Cereal Chem. 40, 450.

Shibasaki, M., Suzuki, S., Tajima, S., Nemoto, H. \& Kuroume, T. (1980). Int. Archs Allergy appl. Immunol. 61, 441 .

Sissons, J. W. \& Smith, R. H. (1976). Br. J. Nutr. 36, 421.

Sissons, J. W. \& Smith, R. H. (1978). J. Physiol., Lond. 283, 307.

Sissons, J. W., Smith, R. H. \& Hewitt, D. (1979). Br. J. Nutr. 42, 477.

Smith, R. H. (1958). Nature, Lond, 182, 260.

Smith, R. H. (1962). Biochem. J. 83, 151.

Smith, R. H. (1964). J. Physiol., Lond. 172, 305.

Smith, R. H. \& Sissons, J. W. (1975). Br. J. Nutr. 33, 329.

Technicon Instruments Co. Ltd (1967). Technicon Methodology Sheet N-36, Basingstoke: Technicon Instruments Co. Ltd.

Wolf, W. J. (1970). J. Agric. Fd Chem. 18, 969. 